\title{
Addition of Tradescantia fluminensis Vell. (Commelinaceae) to the state flora of Sikkim, India
}

\author{
Jayanta Ghosh ${ }^{1}$, Mrinmoy Midday ${ }^{1}$, Manasi Mandal ${ }^{2}$ and Debabrata Maity ${ }^{1,3}$ \\ ${ }^{1}$ Taxonomy and Biosystematics Laboratory, Department of Botany, University of Calcutta, 35 Ballygunge \\ Circular Road, Kolkata - 700 019, West Bengal, India \\ ${ }^{2}$ Department of Botany, Sundarban Hazi Desarat College, Pathankhali, South 24 Pgs, West Bengal, India \\ ${ }^{3}$ Corresponding author; e-mail: debmaity@yahoo.com
}

[Received 16.12.2020; Revised 27.12.2020; Accepted 28.12.2020; Published 31.12.2020]

\begin{abstract}
Tradescantia fluminensis Vell.(Commelinaceae), an invasive exotic species, is recorded from Gangtok and added to the flora of Sikkim for the first time. The diagnostic traits of the species along with field photographs and habitat information is provided. The representative specimens are catalogued in $\mathrm{CUH}$ for future reference.
\end{abstract}

Key words: Exotic, indigenous, flora, migration, phenology, phytosociology.

\section{INTRODUCTION}

Sikkim, the tiny mountainous state, is one of the top species rich areas in the entire Himalaya with its extraordinarily rich indigenous flora and considerable alien elements. This richness may be inferred in values that surpass about 4558 species of angiosperms besides impressive counts from other plant groups (Singh \& Chauhan 1998; Maity et al. 2018; Maity 2020). This enormous plant diversity is enriched through speciation as evident from the discovery of many new species/taxa through the ages as well as records of numerous plant species of the neighboring as well as far away countries which are migrated as a process of plant dispersal and plant migration (Maity \& Maiti 2007). Plant migration helps a species to extend its distributional range in new localities beyond the previous limit of occupied habitat. Tradescantia L. is well known by its ornamental members and is represented by 70 species worldwide (Mabberley 2017). Many of them escape frequently and grow naturally in nearby suitable habitats. In Sikkim and Darjeeling Himalayas two members of the genus, viz. T. pallida (Rose) D.R. Hunt and T. virginiana Linnaeus are well known for their ornamental values and are commonly grown in parks and gardens. In recent years during the study of flora of the state Sikkim, we came across few populations of Tradescantia fluminensis Vell. with luxuriant growth in a small forest patch along the foot trek Near $3^{\text {rd }}$ Mile, Gangtok. Plants were distinct with its characteristic lanceolate-elliptic to ovate-lanceolate leaves, foliaceous bracts and flowers on the long, glandular pilose pedicels which turns drooping after anthesis. The identity of the specimens was confirmed through critical examination of the collected specimens and extensive literature search (Anderson \& Woodson Jr. 1935; Hunt 1980; Nirola \& Das 2018). In recent past, Nirola \& Das (2018) reported the only naturalized habitat of Tradescantia fluminensis in India from lower part of Lloyd Botanic Garden, on the way Tung to Darjeeling. The present observation on the occurrence of the species in Sikkim extends its habitat range to more northern part to the Sikkim Himalaya. Importantly, in 2019 we recorded three populations of this species at Kalimpong district of West Bengal. The representative specimens, collected both from Kalimpong and Sikkim are deposited at CUH for future reference. In the present communication, description of the species based on the diagnostic traits, phytosociological association and habitat information 
368 Occurrence of Tradescantia fluminensis in Sikkim

are provided for correct identification and easy recognition. The other relevant data, like flowering and fruiting time as major source of phenology, world distribution and exsiccata are also provided.

\section{TAXONOMY}

Tradescantia fluminensis Vell., Fl. Flumin. 3: 140, t. 152. 1829; Nirola and Das, Pleione 12(1): 145.2018. T. mundula Kunth, Enum. Pl. 4: 83. 1843. T. tenella Kunth, Enum. Pl. 4: 83. 1843. T. fluminensis var. tenella (Kunth) C.B.Clarke, Monogr. Phan. 3: 295. 1881. [Figure 1]

Decumbent, perennial herb, rooting at lower nodes, forming mats on surface. Leaves ovatelanceolate, 2-5.5 × 1-2.5 cm, entire, acute, \pm ciliolate, surface glabrous, base rounded, extended to greenish, scarious, stem clasping sheath; sheath margin and apex ciliolate. Inflorescence terminal (often from distalmost leaf axil), few-flowered, umbellate cymes, subtended by large leafy bract. Flowers long pedicellate, often drooping; pedicels to $2 \mathrm{~cm}$ long. Sepals lanceolate, green, midvein thairy abaxially. Petals broadly ovate, shining white, not clawed. Stamens 6, all fertile, tequal; filaments white, densely bearded with white hairs towards base; anthers yellow. Style white. Capsules 3-valved.
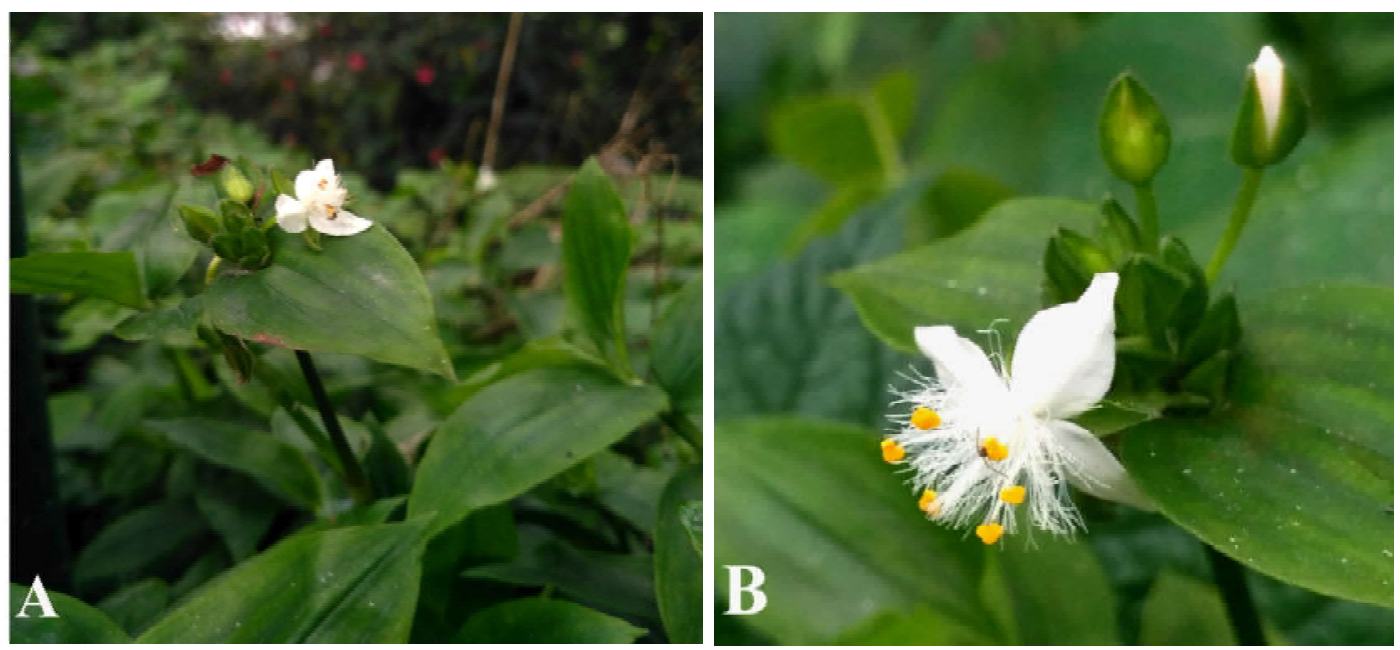

Figure 1. Tradescantia fluminensis: A. Habit; B. Inflorescence

Flowering \& Fruiting: April - July.

Habitat \& phytosociology: T. fluminensis prefers to grow in moist, damp, humid and shady places along small streams, foot treks, edges of forests, and canopy gaps with rich biomass. It grows in continuous patches almost leaving no space in between. However, older parts of the habitat somewhat little cleared due to decaying of old leaves where it is commonly associated with Asplenium sp., Hydrocotyle nepalensis, Lysimachia laxa, Persicaria runcinata, Pilea sp., Plantago major, Rumex nepalensis, Selaginella spp., Viola betonicifolia, etc.

Distribution: India: West Bengal (Darjeeling, Kalimpong), Sikkim (Gangtok); native to the tropical rainforests of south-east Brazil and neighboring areas, widely distributed and naturalized in Australia, Bermuda, Italy, Japan, Kenya, New Zealand, Portugal, Spain, France, Greece, Turkey, Puerto Rico, Russian Federation, Saint Lucia, South Africa, Swaziland, USA.

Note: T. fluminensisis is an invasive species with aggressive growth, often forms a monospecific strand causes replacement of indigenous flora. Eradication is sometimes problematic and 
needs high skill systematic and persistent effort (Brown \& Brown 2015). The presence of this species in Jammu \& Kashmir, Himachal Pradesh, Sikkim and Maharastra is mentioned in different webpages (https://sites.google.com/site/efloraofindia/species/a-l/cl/ commelinaceae/tradescantia/tradescantia-fluminensis; https://www.flowersofindia.net/ catalog/slides/White\%20Spiderwort.html), however, the occurrence in India was authenticated by Nirola \& Das (2018) for the first time from Darjeeling, West Bengal with representative exsiccata. The addition of this species to the flora of Sikkim is confirmed here with representative specimens.

Exsiccata: Sikkim, Gangtok, Near 3 $3^{\text {rd }}$ Mile, 29.05.2019, 2000 m, Ghosh, Midday \& Maity 24014; Kalimpong, Near Kalimpong Govt. College, 15.05.2019, 1400 m, Maity \& Ghosh 23986 [CUH].

\section{Acknowledgements}

Authors are grateful to the Ministry of Environment, Forest and Climate Change, Govt. of India for financial assistance to our research program. CAS, University Grants Commission, Govt. of India is thanked for partial financial assistance. The Department of Forests, Environment and Wildlife Management is warmly thanked for permitting the field visit.

\section{LITERATURE CITED}

Anderson, E. \& Woodson Jr., R. E. 1935. The species of Tradescantia indigenous to the United States. Contr. J. Arnold Arbor. 9: 1 -132. DOI: https://doi.org/10.5962/bhl.title.153160.

Brown, K. \& Brown, D. 2015. Control to eradication of Tradescantia fluminensis on Stephens Island (Takapourewa): the importance of systematic and persistent effort. DOC Research and Development series 346.New Zealand Department of Conservation. The Terrace, Wellington 6143, New Zealand.

Hunt, D.R. 1980. Sections and series in Tradescantia. American Commelinaceae: IX. Kew Bulletin 35: 437 - 442. DOI: https://doi.org/10.2307/4114596.

Mabberley, D.J. 2017. Mabberley's plant-book A portable dictionary of plants, their classification and uses. Ed. 4. Cambridge University Press, Cambridge. p. 931.

Maity, D. 2020. Flora of Sikkim- A Synoptic view. In: Singh, L. J. \& Ranjan, V. (eds.), New Vistas in Indian Flora. Vol. II. Bishen Singh Mahendra Pal Singh, Dehra Dun, India. Pp. $469-496$.

Maity, D. \& Maiti, G.G. 2007. Exotic Plants of Sikkim. Ann. For. 15 (1): 81 - 84.

Maity, D.; Maiti, G.G. \& Chauhan, A. S. 2018. Flora of Kanchenjunga Biosphere Reserve, Sikkim. Botanical Survey of India, Kolkata.

Nirola, S. \& Das, A.P. 2018. Tradescantia fluminensis Vell. (Commelinaceae) : A new record of naturalization in India from West Bengal. Pleione 12(1): 143 - 146.

Singh, P. \& Chauhan, A.S. 1998. An Overview of Plant Diversity of Sikkim. In: Rai, S.C. et al. (eds.), Sikkim Perspectives for Planning and Development. Sikkim Science Society, Tadong, Sikkim. Pp. $219-231$. 